\title{
Ontogenetic diet shifts in the reef fish Pseudanthias rubrizonatus from isolated populations on the North-West Shelf of Australia
}

\author{
David O. Cummings ${ }^{1, *}$, David J. Booth ${ }^{2}$, Raymond W. Lee ${ }^{3}$, Stephen J. Simpson ${ }^{1}$, \\ Adele J. Pile ${ }^{1}$ \\ ${ }^{1}$ School of Biological Sciences (A08), University of Sydney, Sydney, New South Wales 2006, Australia \\ ${ }^{2}$ Department of Environmental Sciences, University of Technology, Sydney, PO Box 123, Sydney, Broadway, \\ New South Wales 2007, Australia \\ ${ }^{3}$ School of Biological Sciences, Washington State University, PO Box 644236, Pullman, Washington 99164-4236, USA
}

\begin{abstract}
The red-barred anthias Pseudanthias rubrizonatus is a common tropical deep reef fish species found in Australia, but little is known about its dietary preferences and trophic interactions. We examined the gut contents and stable isotope signatures $\left(\delta^{13} \mathrm{C}\right.$ and $\left.\delta^{15} \mathrm{~N}\right)$ of $P$. rubrizonatus from populations on the North-West Shelf of Australia to determine differences in diet relative to site, depth and fish size. We sampled 5 fish populations from a series of sub-sea structures, from 82 to $152 \mathrm{~m}$ depth, which had been submerged for up to $15 \mathrm{yr}$. Gut content analysis suggested that $P$. rubrizonatus displays an opportunistic feeding strategy and utilises both pelagic and benthic resources, including larval fishes, heteropods, isopods and mysids. Stable isotope analyses revealed that at all depths P. rubrizonatus underwent an ontogenetic diet shift. Values for $\delta^{13} \mathrm{C}$ in muscle ranged from $-19.7 \%$ for small fish to $-16.2 \%$ for larger individuals, and $\delta^{15} \mathrm{~N}$ ranged from $8.2 \%$ for smaller fish to $13.2 \%$ for larger fish, indicating that a diet shift occurs at the end of juvenile development between 30 and $50 \mathrm{~mm}$ standard length. By simultaneously analysing gut contents and stable isotope signatures of the collected specimens, we have documented opportunistic dietary strategies that may assist $P$. rubrizonatus to colonise isolated structures.
\end{abstract}

KEY WORDS: Stable isotopes $\cdot$ Gut contents $\cdot$ Trophic interactions $\cdot$ Feeding strategies $\cdot$ Petroleum structures $\cdot$ Artificial reefs $\cdot$ Indian Ocean

Resale or republication not permitted without written consent of the publisher

\section{INTRODUCTION}

Fishes may exhibit plastic dietary patterns and diet shifts for a number of reasons, such as increased competition (Ward et al. 2006), changes in resource accessibility and availability (Garicía-Berthou \& MorenoAmich 2000) and developmental changes in size (Scharf et al. 2000) and nutritional requirements (Simpson \& Raubenheimer 2001a). In many cases, diet shifts are associated with behavioural and morphological changes (Ward-Campbell \& Beamish 2005), as exemplified by the cichlid fishes that display high levels of morphological plasticity in relation to their feed- ing niches (Liem 1980, Wimberger 1992, Wagner et al. 2009).

Ontogenetic shifts in diet are common among animal populations that comprise a range of life stages (Werner \& Gilliam 1984, Olson 1996, Muñoz \& Ojeda 1998, Ward-Campbell \& Beamish 2005). Changes in diet between size classes and life stages have been found to be common among fishes (Muñoz \& Ojeda 1998), including freshwater (e.g. Olson 1996, Schleuter \& Eckmann 2008), estuarine (e.g. Eggold \& Motta 1992, St John 1999, Jackson \& Rundle 2008) and reef (e.g. Avise \& Shapiro 1986, Wells et al. 2008) species. It is thought that these shifts are a survival strategy when 
resources are limiting (Werner \& Gilliam 1984), reducing the effects of intraspecific competition (WardCampbell \& Beamish 2005). If so, it is likely that such a strategy is important for fish species colonising isolated habitat patches such as artificial reef structures, where multiple life stages will typically coexist.

We examined feeding of Pseudanthias rubrizonatus among a series of small isolated artificial reefs off north-western Australia. The use of artificial reefs is becoming an increasingly popular management tool to improve fisheries and restore degraded habitats (Miller 2002, Santos \& Monteiro 2007). Artificial reefs increase habitat availability and complexity, boosting local-scale diversity (Wilding \& Sayer 2002). Both current and abandoned petroleum industry infrastructure provides isolated artificial reef structures, such as pipelines, seafloor completions, wellheads (Caselle et al. 2002) and entire platforms at a range of depths. In California (USA), many of these structures harbour high abundances of fishery-depleted species (Love et al. 1999, 2006, Caselle et al. 2002, Love \& York 2005), and may exhibit different assemblage attributes to natural reefs (Wolfson et al. 1979).

Pseudanthias rubrizonatus grows to $120 \mathrm{~mm}$ total length (TL) and is a resident species on the North-West Shelf of Australia. P. rubrizonatus is a small fish commonly encountered on deeper offshore reefs in tropical habitats (Allen 1997). The basic ecology of P. rubrizonatus is relatively undocumented, and like many members of the Serranidae, the genus is dimorphic and protogynous (Shapiro 1988, 1990). Populations of $P$. rubrizonatus on artificial structures in deeper water off north-western Australia change from females to males after approximately $50 \mathrm{~mm}$ standard length (SL; A. Fowler unpubl.), a size which will vary between populations due to social structure regardless of body size (Shapiro 1988).

The feeding ecology of Pseudanthias rubrizonatus is undocumented. However, in common with other members of the genus, the species appears to be predominantly planktivorous (Shapiro \& Genin 1993). However, $P$. rubrizonatus is likely to be an opportunistic piscivore when larval or post-larval fishes are abundant within the plankton community. Many serranid reef fishes are known to be opportunistic predators, and those that are generally regarded as piscivorous prey on a range of benthic and pelagic species where available (e.g. Hood et al. 1994). Such opportunistic or generalist feeding strategies may provide fishes like $P$. rubrizonatus with the ability to colonise and survive in locations with limited and variable food resources.

A variety of forensic techniques are used to determine an animal's diet. Gut analysis provides information about the most recent prey consumed (Kolasinski et al. 2009), but does not reflect diet in the longer term.
Direct gut analysis can, in many cases, be logistically difficult (Vander Zanden et al. 1998) and lead to uncertainty when prey items are partially digested and difficult to identify (Kolasinski et al. 2009). In addition to contents, changes in the morphology of the alimentary canal, such as the ratio of gut length to size, can provide an indication of trophic position in fishes (Kapoor et al. 1976, Clements \& Choat 1993, German \& Horn 2006, Wagner et al. 2009). Stable isotopes are widely used to investigate trophic interactions and assist in identifying energy flow (Post 2002) and dietary preferences (Webb et al. 1998). The ratio of stable carbon $\left({ }^{13} \mathrm{C} /{ }^{12} \mathrm{C}\right)$ and nitrogen $\left({ }^{15} \mathrm{~N} /{ }^{14} \mathrm{~N}\right)$ isotopes in animal tissue can be used to trace food webs and detect differences in trophic position. In general, $\delta^{13} \mathrm{C}$ is reflective of the primary producers in the animal's food web (DeNiro \& Epstein 1978), with enrichment between trophic levels typically between 0 and $1 \%$ (Fry \& Sherr 1984). $\delta^{15} \mathrm{~N}$ increases with trophic level in animal tissue (Cherel et al. 2005). This stepwise enrichment of $\delta^{15} \mathrm{~N}$ is generally 3 to $4 \%$ per trophic level (Minagawa \& Wada 1984), allowing the trophic position of the animal to be estimated (Wada et al. 1987) - with caveats.

The interpretation of stable isotope values in relation to an animal's trophic position should be made with care, as it is reliant on assumptions that are often not met, since animals assimilate nutrients at variable efficiencies, isotopes undergo fractionation within animal tissues, and nutrients may be allocated differentially to specific tissues (Gannes et al. 1997). Isotope values of a given tissue are also dependent on turnover; tissues with fast turnover rates are more reflective of recent diet (Hobson 1999). In tissues such as muscle with lower turnover rates, the isotopic composition generally integrates diet over longer periods, with the signal from early diet being lost to some degree due to turnover and catabolism (Hesslein et al. 1993).

Despite the problems inherent in each of the aforementioned techniques for estimating an animal's diet, together they can provide insights into trophic interactions within food webs and dietary shifts within populations. We aimed to determine whether populations of Pseudanthias rubrizonatus living on artificial reefs on the North-West Shelf of Australia exhibit ontogenetic diet shifts using gut analysis and isotope analysis, to infer the feeding ecology of this poorly studied species.

\section{MATERIALS AND METHODS}

Study area and specimen collection. During the winter of 2008, specimens of Pseudanthias rubrizonatus (Randall 1983) were collected from communities that had colonised offshore sub-sea structures (artificial reefs). These were wellheads, i.e. structures con- 
sisting of a number of steel pipes and valves positioned on the surface of well holes at the completion of drilling. The wellheads were located in water at depths between 82 and $152 \mathrm{~m}$ on the North-West Shelf, in an area 110 to $135 \mathrm{~km}$ northwest of Karratha in Western Australia. These wellheads had been in place on the seafloor for up to $15 \mathrm{yr}$ and consequently had developed into extensive artificial reefs with vertebrate fauna dominated by the study species. The collection sites included the Goodwyn, Echo, Yodel, Cossack and Wanaea fields (ranging from $19^{\circ} 33^{\prime} 08^{\prime \prime}$ to $19^{\circ} 44^{\prime} 40^{\prime \prime} \mathrm{S}$, and $115^{\circ} 43^{\prime} 12^{\prime \prime}$ to $116^{\circ} 29^{\prime} 50^{\prime \prime} \mathrm{E}$ ).

Six wellheads, approximately $4 \mathrm{~m}$ high, $2 \mathrm{~m}$ wide and $2 \mathrm{~m}$ deep, were severed below the sea bed. Once severed, the wellheads were lifted from the sea floor, generally in 2 pieces, onto CV 'Havila Harmony'. During the retrieval, the high structural complexity of the wellhead coupled with the abundance of Pseudanthias rubrizonatus resulted in many fish becoming entrapped within the structures and allowed for the collection of fish ranging in size from 10 to $120 \mathrm{~mm}$. Given that this covers the size range expected for this species, it seems likely that the samples reflect all post-larval stages.

Because the wellheads and any associated structures were removed in their entirety, opportunities for subsequent sampling were limited. However, at the Goodwyn location, the wellhead was removed over $2 \mathrm{~d}$, the first piece on 18 July 2008 and the second adjacent piece a month later on 24 August 2008, providing 2 collections of the study species. Once on board the vessel, Pseudanthias rubrizonatus were collected from the wellheads, immediately frozen to $-20^{\circ} \mathrm{C}$ and shipped frozen to the University of Sydney. All specimens were checked for correct identification, and morphometric measurements of the specimens were obtained. Digestive tracts $(n=393)$ were dissected from the anterior of the stomach to the anus and their lengths (gut length, GL) recorded to the nearest millimetre, taking care to minimise stretching (German \& Horn 2006). Some digestive tracts $(n=161)$ were stored in $10 \%$ formalin for later quantification of gut contents. A small amount of muscle tissue was taken from between the caudal and dorsal fin and stored at $-20^{\circ} \mathrm{C}$ for stable isotope analysis $(\mathrm{n}=214)$.

Otolith (earstone) aging of these specimens showed that the majority of juveniles (defined as fish less than 1 yr in age) were $<30 \mathrm{~mm}$ SL (A. Fowler unpubl. data). Because body colouring and gonad size can be used to distinguish sex, it was also possible to determine that the majority of females had changed sex to males by $60 \mathrm{~mm}$ SL at all locations (A. Fowler unpubl. data). Therefore, we assumed that size provided an indication of ontogenetic stage and sex. The size classes used in this study covered the 3 major post-settlement life history stages: Small (<30 mm: juveniles), Medium (30-60 mm: females) and Large (>60 mm: males).

Gut content analysis. The stomach contents of the 3 size classes of Pseudanthias rubrizonatus were determined with the aid of an Olympus dissecting microscope at $40 \times$ magnification. Stomach contents were classified either as identifiable or unidentifiable material. The total mass of unidentifiable material was determined to the nearest $0.01 \mathrm{mg}$, whereas identifiable material was sorted into functional groups, blotted dry, counted and weighed, and the total mass for each prey type determined. Identifiable prey items were subsequently stored in $70 \%$ ethanol for stable isotope analysis.

Data on each prey type were converted to percent of total gut content weight for analysis, and used to derive indices of the assemblages of prey species that were identifiable within the guts. Only data from the Yodel, Goodwyn and Wanaea locations were used because there were insufficient data from other locations. A standardised index of relative importance (\%IRI; Cortes 1997) was chosen to determine the importance of each prey item for each of the 3 size classes and locations, incorporating number $(\mathrm{N})$, weight (W) and frequency of occurrence (F) per fish (Hyslop 1980).

$$
\% \operatorname{IRI}=[(\% \mathrm{~N}+\% \mathrm{~W}) \times \% \mathrm{~F}] \times 100
$$

These prey assemblage data were then binomial transformed and analysed with a principle coordinates analysis (PCO), to reduce the dimensions of the dataset and determine relationships between key variables (Jolliffe 2004). To identify the reliability of the factors derived from the PCO in assigning a fish to a location or size class, discriminate analysis with jack-knifing was performed on the first 3 sets of principle component scores.

Digestive tract morphology. An analysis of covariance (ANCOVA) was performed with site as treatment, GL as the dependent variable and SL of fish as the covariate. Slope assumptions were tested by fitting the full ANCOVA model with an interaction term (Quinn \& Keough 2002). As a significant interaction was encountered and heterogeneous variances were found for the refitted model, Tukey's test for multiple comparisons of slope was used (Zar 1984). This allowed for significance in differences in the ratio of GL to SL (slope) to be determined between locations.

Stable isotope analysis. Frozen muscle samples were freeze dried (Christ Epsilon 2-6D) to a constant mass, and then a small (approximately $1 \mathrm{mg}$ ) piece of muscle tissue was removed for measurements of $\delta^{13} \mathrm{C}$ and $\delta^{15} \mathrm{~N}$. For prey species found in the foreguts of Pseudanthias rubrizonatus, only whole relatively undigested specimens were used. For some small prey 
items, individuals were pooled to gain a sample mass of approximately $1 \mathrm{mg}$. Once freeze dried, whole samples of prey species were then homogenised. Prey items which contained calcium carbonate, such as heteropods, were washed in phosphoric acid to remove inorganic carbon. As prey items had been fixed in $10 \%$ formalin and preserved in $70 \%$ ethanol, samples were tested for the required correction by comparing isotope values for both frozen and preserved material. This analysis confirmed that $\delta^{15} \mathrm{~N}$ required no correction, whereas $\delta^{13} \mathrm{C}$ samples required a $+1.7 \%$ correction when preserved samples were used. The stable isotope analysis was performed at Washington State University. A Costech elemental analyser with a 0-blank autosampler that can routinely measure isotope values from samples as small as $0.1 \mathrm{mg}$ was interfaced with an Isoprime isotope ratio mass spectrometer (IRMS) to determine isotope values (Yohannes et al. 2008).

ANCOVA was employed to examine the changes in isotope signatures of $\delta^{13} \mathrm{C}$ and $\delta^{15} \mathrm{~N}$ (dependent variables) as a function of SL of fish (covariate) and location (factor). The assumption of parallel slopes was tested by fitting the full ANCOVA model with an interaction term (Quinn \& Keough 2002) and homogeneity of variance was tested using Levene's test. Where homogeneity of variances was not achieved and significant results were encountered, the null hypothesis was only rejected when p-values were found to be lower than the test for homogeneity of variance (Underwood 1981).

\section{RESULTS}

\section{Gut content analysis}

Within a location, patterns in the proportion of distinguishable and undistinguishable material were similar between the 3 size classes, but differed between locations and sampling time (PCO, Fig. 1). Fish with gut contents that were most distinguishable, indicating they had recently eaten, were those of the first collection at the Goodwyn and Yodel sites. However, fish collected 1 mo later at Goodwyn (second collection) had mainly indistinguishable material within their guts. Medium and large fish from Wanaea had material in their guts of which half was distinguishable, suggesting they may not have eaten as recently as other fish. Owing to small sample sizes and many empty guts, patterns were difficult to interpret for the other locations and size classes.

Values of \%IRI indicated that smaller zooplankton, such as heteropods, mysids and hyperiid amphipods, were key prey items for all sizes of Pseudanthias rubrizonatus. While not as regularly found in the guts of $P$.

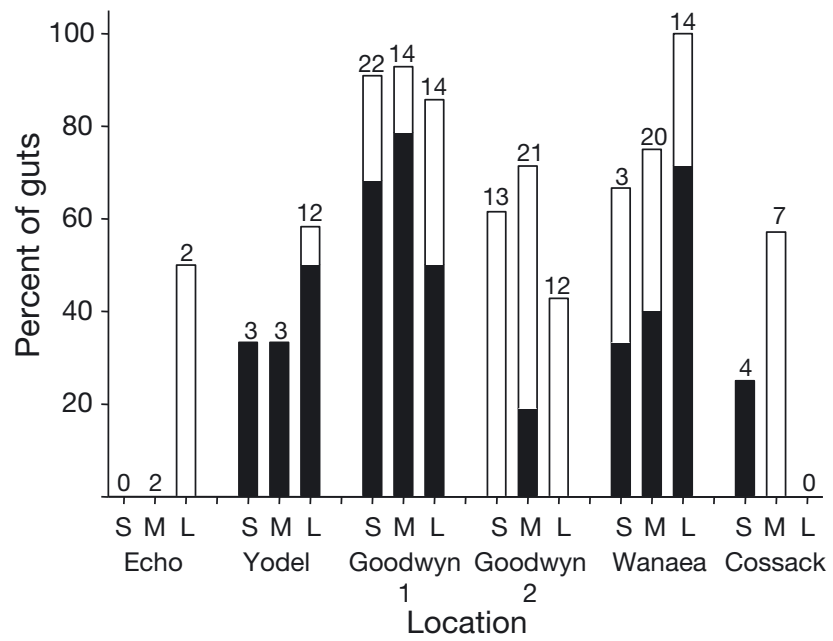

Fig. 1. Pseudanthias rubrizonatus. Fish with material in their guts categorised as a percent of total fish with distinguishable (black bars) and undistinguishable (open bars) material for 3 sizes (S: Small, M: Medium, L: Large) at each location: Echo $($ depth $=152 \mathrm{~m})$, Yodel $(137 \mathrm{~m})$, Goodwyn $(136 \mathrm{~m})$, Wanaea $(84 \mathrm{~m})$ and Cossack $(82 \mathrm{~m})$. Number above each bar is the sample size. Fish were collected at Goodwyn on 18 July 2008 (Goodwyn 1) and 24 August 2008 (Goodwyn 2)

rubrizonatus, large prey items such as larval bregmacerotids (Bregmacerotidae) were recorded in guts of large fish, especially at the shallower location (Wanaea). In contrast, at deeper locations (Yodel and Goodwyn), smaller prey items, such as benthic isopods, shrimp, pelagic mysids, heteropods and hyperiid amphipods, were more common in the gut than larger items such as larval fishes (Table 1).

Comparisons of \%IRI values across size classes indicated a tendency of both smaller and larger individuals to rely on small pelagic prey such as heteropods and mysids. However, much smaller prey such as hyperiid amphipods and copepods were important for fish in the small size class (Table 1).

The diet of Pseudanthias rubrizonatus varied as a function of time and location but not size class (Table 2 , Fig. 2). PCO revealed that $63.7 \%$ of the total variance was accounted for in the first 3 components. The first component explained $36.3 \%$ of the variance, and the loadings for each factor revealed that heteropods (loading factor $=4.79$ ) were negatively correlated with mysids B (loading factor $=-0.97$ ) and bregmacerotids (loading factor $=-0.949$ ). For the second component, which explained $18.2 \%$ of the variance, mysids B (loading factor $=2.99$ ) and bregmacerotids (loading factor $=1.212$ ) were strongly correlated with each other. For the third component, which explained 9.2\% of the variance, hyperiid amphipods (loading factor $=$ 1.819) were negatively correlated with tintinnia (loading factor $=-1.169$ ). A bi-coordinate plot of the load- 
Table 1. Prey items in guts of Pseudanthias rubrizonatus as determined by the highest percent index of relative importance (\%IRI, shown in parentheses), at Yodel, Goodwyn and Wanaea, and by size of the fish (Small, Medium, Large). Fish were collected at Goodwyn on 18 July 2008 (Goodwyn 1) and 24 August 2008 (Goodwyn 2). id: insufficient data

\begin{tabular}{|c|c|c|c|}
\hline Location/depth & Small & Medium & Large \\
\hline $\begin{array}{l}\text { Yodel } \\
137 \mathrm{~m}\end{array}$ & $\begin{array}{l}\text { id } \\
\text { id } \\
\text { id }\end{array}$ & $\begin{array}{l}\text { id } \\
\text { id } \\
\text { id }\end{array}$ & $\begin{array}{l}\text { Hyperiids (48.97) } \\
\text { Shrimp (19.57) } \\
\text { Isopods (16.64) }\end{array}$ \\
\hline $\begin{array}{l}\text { Goodwyn } 1 \\
136 \mathrm{~m}\end{array}$ & $\begin{array}{c}\text { Heteropods (94.21) } \\
\text { Copepods (2.80) } \\
\text { Hyperiids }(2.15)\end{array}$ & $\begin{array}{c}\text { Heteropods }(98.60) \\
\text { Crab larvae }(0.45) \\
\text { Shrimp C }(0.38)\end{array}$ & $\begin{array}{l}\text { Heteropods (85.74) } \\
\text { Mysids B (14.25) } \\
\text { id }\end{array}$ \\
\hline $\begin{array}{l}\text { Goodwyn } 2 \\
136 \mathrm{~m}\end{array}$ & $\begin{array}{l}\text { id } \\
\text { id } \\
\text { id }\end{array}$ & $\begin{array}{c}\text { Pteropods (48.92) } \\
\text { Shrimp (27.79) } \\
\text { Amphipods (23.20) }\end{array}$ & $\begin{array}{l}\text { id } \\
\text { id } \\
\text { id }\end{array}$ \\
\hline $\begin{array}{l}\text { Wanaea } \\
84 \mathrm{~m}\end{array}$ & $\begin{array}{l}\text { id } \\
\text { id } \\
\text { id }\end{array}$ & $\begin{array}{l}\text { Mysids B (80.36) } \\
\text { Isopods (9.98) } \\
\text { Shrimp (4.58) }\end{array}$ & $\begin{array}{c}\text { Mysids B (63.12) } \\
\text { Bregmacerotids (36.39) } \\
\text { Amphipods }(0.49)\end{array}$ \\
\hline
\end{tabular}

Table 2. Factor loadings, eigenvalues and percentages of variance from principle coordinate analysis for the first 3 components for prey items of Pseudanthias rubrizonatus. Highest factor loadings are in bold

\begin{tabular}{|lrrr|}
\hline Prey item & \multicolumn{3}{c|}{ Factor } \\
& 1st & 2nd & 3rd \\
\hline Crab larvae & -0.038 & -0.529 & -0.801 \\
Isopods & -0.691 & -0.639 & 0.758 \\
Hyperiids-Amphipoda & -0.374 & -1.093 & $\mathbf{1 . 8 1 9}$ \\
Amphipods & -0.539 & -0.414 & 0.394 \\
Mysids A & -0.585 & -0.305 & -0.375 \\
Mysids B & $-\mathbf{0 . 9 7 0}$ & $\mathbf{2 . 9 9 0}$ & 0.364 \\
Heteropods & $\mathbf{4 . 7 9 0}$ & 0.500 & 0.140 \\
Pterepods & -0.589 & -0.356 & -0.614 \\
Copepods & 0.642 & -0.284 & 0.021 \\
Bregmacerotids & $-\mathbf{0 . 9 4 9}$ & $\mathbf{1 . 2 1 2}$ & -0.131 \\
Tintinnia & -0.091 & -0.586 & $\mathbf{- 1 . 1 6 9}$ \\
Ectodinomorphida & -0.605 & -0.495 & -0.406 \\
Eigenvalues & 27.176 & 13.605 & 6.899 \\
Percentage & 36.315 & 18.18 & 9.219 \\
Cumulative percentage & 36.315 & 54.495 & 63.714 \\
& & & \\
\hline
\end{tabular}

ings for the first 2 components shows that heteropods and to a lesser extent copepods could be used to identify diets of fish sampled from the Goodwyn 1 location. In contrast, diets of fish from the Wanaea location could be identified by mysids B and to a lesser extent bregmacerotids.

In order to test the reliability of the loadings in assigning a fish to its correct location, a discriminate analysis with jack-knifing was performed on the first 3 axes derived from the PCO. This analysis determined that, overall, $71 \%$ of fish could be assigned to a location based on the prey items in their guts. Most (91\%) fish from the first sample of the Goodwyn location and $86 \%$ of fish from the Wanaea location could be reliably assigned to a location, while none from the Yodel and

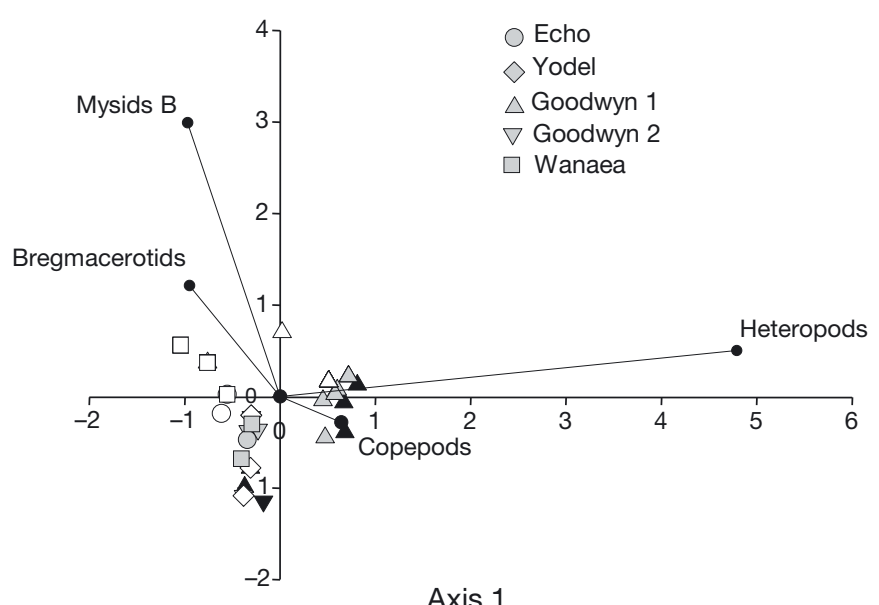

Axis 1

Fig. 2. Pseudanthias rubrizonatus prey assemblage bi-coordinate plot of the first 2 components of principle coordinates analysis output for differences in between locations (shape) and size class (shading). Echo (circles, depth $=151 \mathrm{~m}, \mathrm{n}=3$ ), Goodwyn 1 (triangles, $131 \mathrm{~m}, \mathrm{n}=33$ ), Goodwyn 2 (inverted triangles, $131 \mathrm{~m}, \mathrm{n}=5$ ), Yodel (squares, $135 \mathrm{~m}, \mathrm{n}=4$ ) and Wanaea (diamonds, $84 \mathrm{~m}, \mathrm{n}=14$ ). Small (black, $\mathrm{n}=16$ ), Medium (gray, $\mathrm{n}=22$ ) and Large (white, $\mathrm{n}=21$ ). Fish were collected at Goodwyn on 18 July 2008 (Goodwyn 1) and 24 August 2008 (Goodwyn 2). Binomial transformation of data

Echo locations, or the second sample of the Goodwyn location could be reliably assigned a location based on gut contents.

Re-analysis of the data using fish size classes (Small, Medium, Large) was performed, but location was found to be a better predictor of gut content than fish size. A bi-coordinate plot of the loadings for the first 2 factors shows that the prey items mysids B and bregmacerotids may be useful in distinguishing fish from the large size class (Fig. 2). However, results of the discriminate analysis with jack-knifing found the data to be much less reliable, and only $44 \%$ of the total num- 
ber of fish could be assigned to the correct size class (Small: $44 \%$; Medium: 32\%; Large: $57 \%$ ).

\section{Digestive tract allometry}

The GL of Pseudanthias rubrizonatus increased linearly with SL at all locations. The slope $(b)$ of this relationship displayed a gradient between 1 and 1.4 at each location (Fig. 3). The multiple comparisons of gradients from the regressions at each location using a Tukey's test revealed that fish from Wanaea $(b=1.411)$

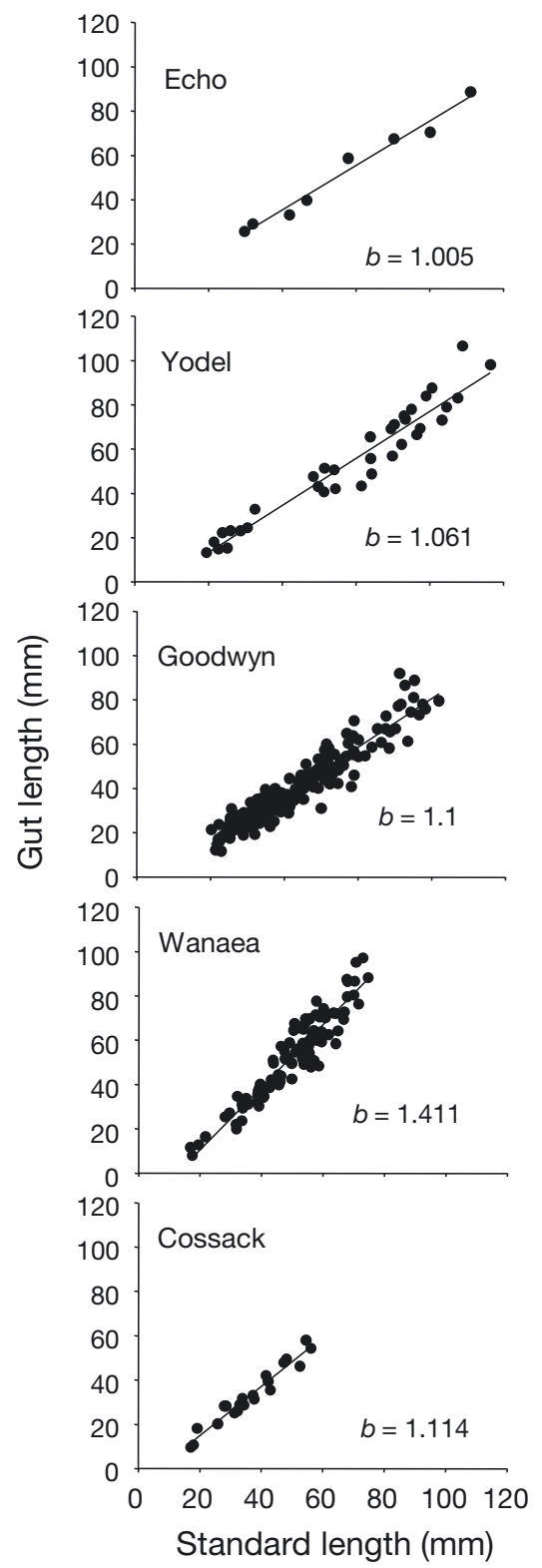

Fig. 3. Pseudanthias rubrizonatus. Gut length against standard length of fish at each location: Echo (depth $=152 \mathrm{~m})$, Yodel $(137 \mathrm{~m})$, Goodwyn $(136 \mathrm{~m})$, Wanaea $(84 \mathrm{~m})$ and Cossack $(82 \mathrm{~m}) . b=$ slope had a significantly steeper slope compared to fish from all other locations. Samples from Echo $(b=1.005)$ had a significantly lower ratio of increase than those from Goodwyn $(b=1.1)$, Yodel $(b=1.061)$ and Cossack $(b=1.114)$ sites, which did not differ from each other (Table 3).

\section{Stable isotope analysis}

Stable isotope signatures of Pseudanthias
rubrizonatus

$\delta^{13} \mathrm{C}$ and $\delta^{15} \mathrm{~N}$ values for $P$. rubrizonatus muscle tissue became more enriched with fish size regardless of location (Fig. 4). An examination of $\delta^{13} \mathrm{C}$ and $\delta^{15} \mathrm{~N}$ as a function of fish length suggested changes in diet for $P$. rubrizonatus as size increased (Fig. 5). An ANCOVA was performed with a covariate by factor interaction term fitted to the model (Intercept + Location $+\mathrm{SL}+$ Location $\times \mathrm{SL}$ ), to test for differences in slope. A significant interaction term was encountered for both the $\delta^{13} \mathrm{C}$ (Table 4A) and $\delta^{15} \mathrm{~N}$ (Table 5A) values.

Inspection of the data (Fig. 4) suggested that a single location, Yodel, was driving the interaction effect. Unlike all other locations, $\delta^{13} \mathrm{C}$ and $\delta^{15} \mathrm{~N}$ values did not change with increasing fish size (Fig. 5). Fish at Yodel $<40 \mathrm{~mm}$ SL had much higher signatures for both $\delta^{13} \mathrm{C}$ and $\delta^{15} \mathrm{~N}$ isotopes than small fish at other locations (Fig. 4). The ANCOVA, with the above fitted interaction model, was then performed with the Yodel location removed from that dataset, and the significant covariate by factor interaction terms for both $\delta^{13} \mathrm{C}$ (Table 4B) and $\delta^{15} \mathrm{~N}$ (Table 5B) disappeared. Because the significant interaction terms were removed, an ANCOVA with a standard model testing the main effect was performed for both $\delta^{13} \mathrm{C}$ and $\delta^{15} \mathrm{~N}$. Subsequent results indicated that the covariate of SL was significant for both $\delta^{13} \mathrm{C}$ (Table $4 \mathrm{C}$ ) and $\delta^{15} \mathrm{~N}$ (Table $5 \mathrm{C}$ ), while there were no significant differences between locations for both $\delta^{13} \mathrm{C}$ and $\delta^{15} \mathrm{~N}$.

Another ANCOVA was performed to determine if the smaller fish at Yodel were responsible for the original significant interaction. The interaction term (Location $\times$ Fish Length) was fitted to the model and the ANCOVA was performed, but with the Yodel fish $<40 \mathrm{~mm}$ removed from the dataset. This again removed the significant interaction term for both $\delta^{13} \mathrm{C}$ (Table 4D) and $\delta^{15} \mathrm{~N}$ (Table 5D) isotopes, indicating that the small fish at the Yodel location were responsible for the significant interaction.

The form of the isotopic shift with size could be visualised by using thin-plate splines to fit a response surface for fish length onto a bi-coordinate plot of $\delta^{13} \mathrm{C}$ versus $\delta^{15} \mathrm{~N}$, using data from all locations except Yodel 
Table 3. Pseudanthias rubrizonatus. (A) Regression analysis of gut length (GL) and standard length (SL) at each location. All regressions were highly significant $(\mathrm{p}<0.001)$. Different superscript letters after slope values indicate differences between locations by Tukey's post hoc test results. (B) Tukey's post hoc test results to compare slopes between each location. NS: no significant difference; asterisks indicate significant difference at ${ }^{*} \mathrm{p}<0.05$ and ${ }^{* * *} \mathrm{p}<0.001$

\begin{tabular}{|c|c|c|c|c|c|c|c|c|}
\hline \multicolumn{9}{|c|}{ (A) Regression analysis } \\
\hline Location & Sourc & rariation & SS & df & MS & $F$ & $\mathrm{r}^{2}$ & Slope $(b)$ \\
\hline \multirow[t]{2}{*}{ Echo } & Regre & & 3599.27 & 1 & 3599.27 & 238.64 & 0.99 & $1.005^{\mathrm{a}}$ \\
\hline & Error & & 90.5 & 6 & 15.1 & & & \\
\hline \multirow[t]{2}{*}{ Yodel } & Regre & & 20580.92 & 1 & 20580.92 & 427.74 & 0.96 & $1.061^{\mathrm{a}, \mathrm{b}}$ \\
\hline & Error & & 1635.9 & 34 & 48.1 & & & \\
\hline \multirow[t]{2}{*}{ Goodwyn } & Regre & & 52381.21 & 1 & 52381.21 & 2237.22 & 0.95 & $1.1^{\mathrm{b}}$ \\
\hline & Error & & 5338.3 & 228 & 23.4 & & & \\
\hline \multirow[t]{2}{*}{ Wanaea } & Regre & & 30853.83 & 1 & 30853.83 & 720.62 & 0.94 & $1.411^{\mathrm{c}}$ \\
\hline & Error & & 4110.3 & 96 & 42.8 & & & \\
\hline \multirow[t]{2}{*}{ Cossack } & Regre & & 3308.78 & 1 & 3308.78 & 332.64 & 0.97 & $1.114^{\mathrm{b}}$ \\
\hline & Error & & 189 & 19 & 10 & & & \\
\hline \multicolumn{9}{|c|}{ (B) Slope comparison matrix } \\
\hline & Echo & Yodel & Goodwyn & \multicolumn{2}{|c|}{ Wanaea } & & & \\
\hline Yodel & NS & & & & & & & \\
\hline Goodwyn & ${ }^{*}$ & NS & & & & & & \\
\hline Wanaea & $* * *$ & $* * *$ & $* * *$ & & & & & \\
\hline Cossack & ${ }^{* * *}$ & NS & NS & & & & & \\
\hline
\end{tabular}

fish $<40 \mathrm{~mm}$ (Fig. 6). Tissue $\delta^{13} \mathrm{C}$ and $\delta^{15} \mathrm{~N}$ became more enriched as the SL of the fish increased, but the ratio of $\delta^{13} \mathrm{C}$ and $\delta^{15} \mathrm{~N}$ in the tissue did not change (Fig. 6). The contours of the spline surface indicated that the shift in isotopic enrichment occurred most rapidly between the sizes of 35 and $50 \mathrm{~mm}$.

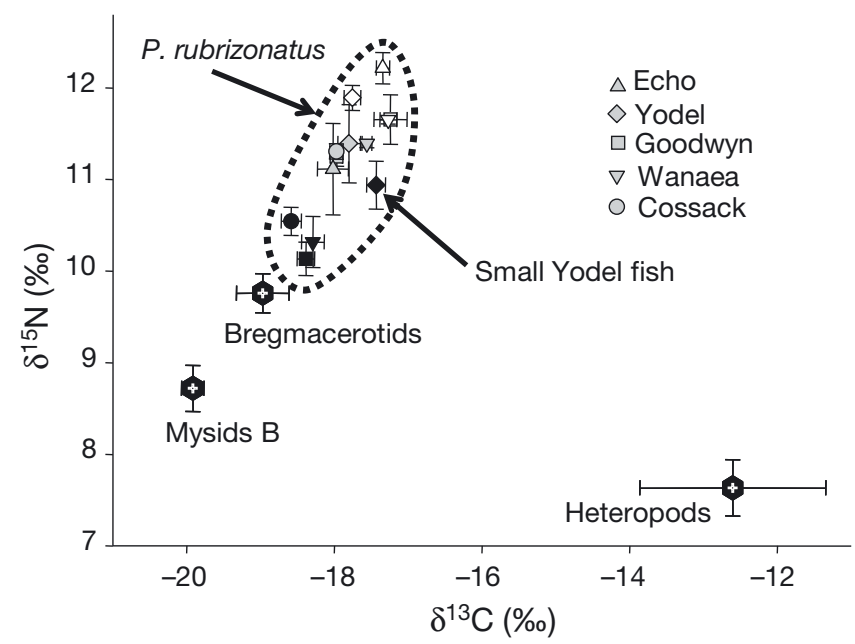

Fig. 4. Pseudanthias rubrizonatus. Bi-coordinate plot of mean stable isotope signatures of $\delta^{13} \mathrm{C}$ vs. $\delta^{15} \mathrm{~N}$ for each size class (Small, Medium, Large) and location: Echo (depth $=152 \mathrm{~m}$ ), Yodel (137 m), Goodwyn (136 m), Wanaea (84 m) and Cossack $(82 \mathrm{~m})$. Additional symbols indicate isotopic signatures for prey items from the guts of the fish (mysids B: $\mathrm{n}=6$, bregmacerotids: $\mathrm{n}=8$, heteropods: $\mathrm{n}=7$ ). Symbols for $P$. rubrizonatus size classes as in Fig. 2
Stable isotope signatures of prey items

The stable isotope signatures for the prey items analysed were well separated from each other in terms of $\delta^{13} \mathrm{C}$ and $\delta^{15} \mathrm{~N}$ (Fig. 4). Mysids B and bregmacerotids were similarly depleted in $\delta^{13} \mathrm{C}$ and $\delta^{15} \mathrm{~N}$, whereas heteropods were the most enriched. Signatures for $\delta^{15} \mathrm{~N}$ for all 3 prey items analysed indicate they were approximately 3 to $4 \%$ less enriched than the majority of their fish predators (Fig. 4).

\section{DISCUSSION}

We have demonstrated that populations of Pseudanthias rubrizonatus on the North-West Shelf display attributes of an opportunistic predatory fish species, and are able to utilise a range of available resources. We have also presented evidence of a diet shift in $P$. rubrizonatus as fish size increases. Shifting diet may be an essential strategy for species in isolated populations, such as those on artificial reefs in deeper water that rely on limited and variable resources. Gut analysis indicated that food resources may be both spatially and temporally variable for these fish populations. Stable isotope analysis suggested that multiple populations of $P$. rubrizonatus display similar trends of isotopic enrichment throughout ontogeny.

Many recent studies have used a combination of gut analysis and stable isotope techniques to investigate 

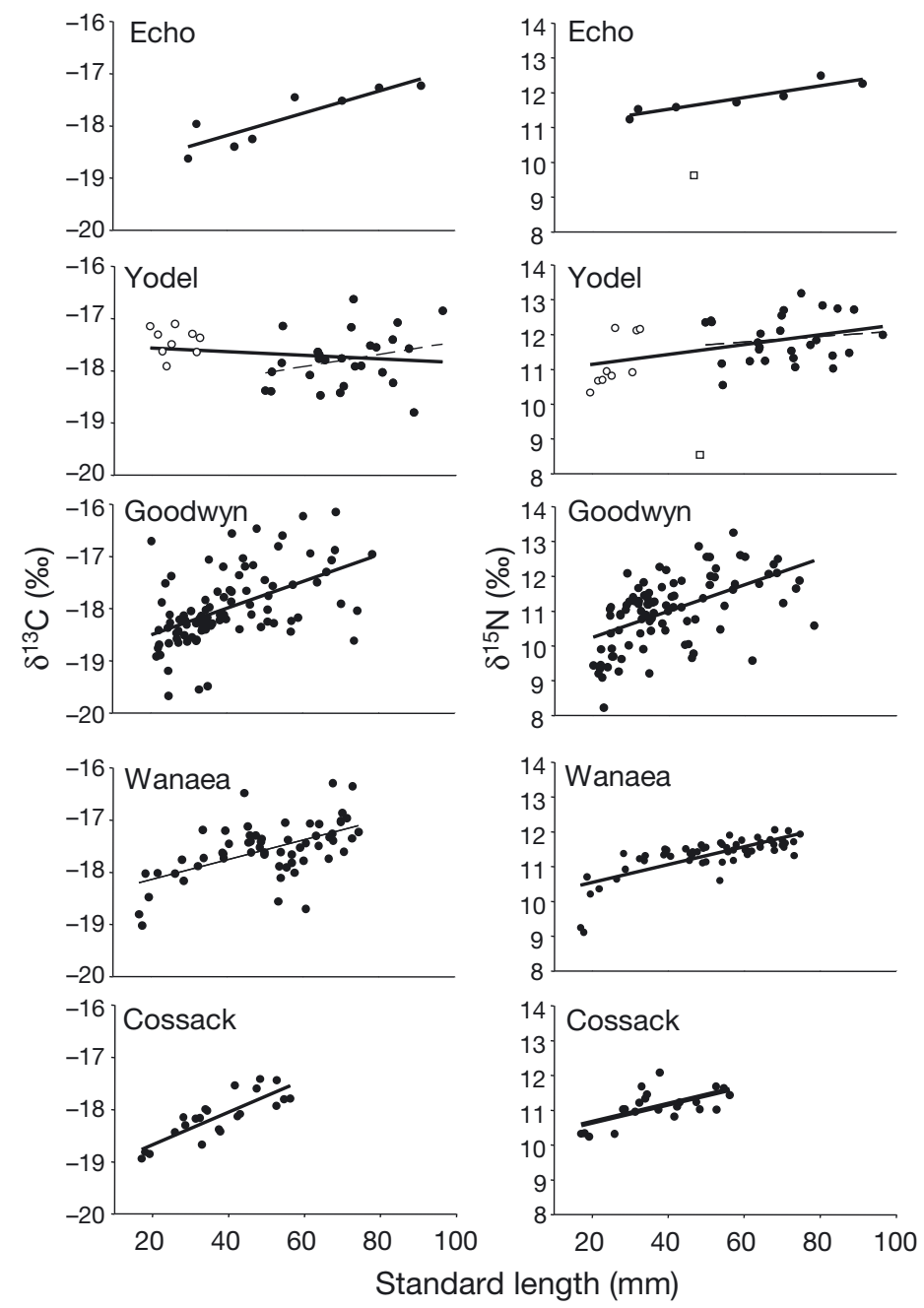

Fig. 5. Pseudanthias rubrizonatus. Stable isotopes of $\delta^{13} \mathrm{C}$ and $\delta^{15} \mathrm{~N}$ against standard length (SL) at the 5 locations: Echo (depth $=151 \mathrm{~m}, \mathrm{n}$ =7), Yodel (135 m, n= 36), Goodwyn (131 m, n = 94), Wanaea (84 m, n = 55) and Cossack $(82 \mathrm{~m}, \mathrm{n}=22)$. White squares show outliers; dashed line in Yodel is the regression refitted after data from small fish $(<40 \mathrm{~mm}$; white circles) were removed

trophic interactions (Clarke et al. 2005, Paradis et al. 2008, Wells et al. 2008, Quevedo et al. 2009). In the present study, gut analysis provided a description of recently ingested prey items, and the stable isotope analysis quantified diet integrated over longer periods of time. The isotopic composition of an animal reflects recent and past diet. The degree to which past diet is represented depends on tissue turnover, which may be affected by high growth rates (Perga \& Gerdeaux 2005). Based on otolith analysis, growth rates for these specimens were determined to range from approximately 10 to $20 \mathrm{~mm} \mathrm{SL} \mathrm{yr}^{-1}$ (A. Fowler unpubl. data), indicating that the isotopic signatures reported reflect long-term diet and are not confounded by excessive rates of growth (Hesslein et al. 1993). Regardless of growth rate, a change in isotope composition in older specimens is indicative of a dietary shift.

The rate of increase in GL as a proportion of SL was approximately 1.1, well within the range of carnivorous species (0.6 to 2.4; Horn 1989). These values were similar at all locations, with the exception of one of the shallower locations (Wanaea). Fish at Wanaea had a proportion of GL to SL of 1.4, suggesting that the diet of these fish was of different quality than those of other populations. Closer inspection of the data revealed that this high slope was driven by disproportionately long GLs amongst the larger fish at the Wanaea site (Fig. 3). Increasing GL can reflect herbivory and decreased diet quality in fishes (Clements \& Choat 1993), and may also indicate a lower trophic position (Wagner et al. 2009) and proteindeficient food resources (German \& Horn 2006) for carnivorous species, but there was no indication of such a trophic shift from our stable isotope data (Fig. 5).

Zooplankton, such as small mysids and heteropods, were evidently important prey items to these populations; however, Pseudanthias rubrizonatus also utilised benthic resources, such as amphipods and isopods, especially at some of the deeper locations. The range in diversity of prey items found in the stomachs indicates that $P$. rubrizonatus are opportunistic feeders. Such strategies are common amongst fishes, including coral trout Plectropomus leopardus (Samoilys 1997), three-spined stickleback Gasterosteus aculeatus (Gill \& Hart 1999), blacktail comber Serranus atricauda (Morato et al. 2000), deeper species of grenadier Macrourus carinatus and $M$. holotrachys (Laptikhovsky 2005), and painted greenling Oxylebius pictus, which eats exotic amphipod species on artificial structures such as oil platforms (Page et al. 2007). Opportunistic feeding strategies are essential to take advantage of temporal influxes of pelagic prey items, especially within resource-deprived communities (Wiens 1993).

As Pseudanthias rubrizonatus became larger, they shifted their diet from smaller prey items such as mysids and heteropods to larger prey, including small or larval fishes. Similar ontogenetic shifts in prey size have been observed in Plectropomus leopardus (Kingsford 1992, St John 1999) and Serranus atricauda (Morato et al. 2000). A shift towards eating larger prey may occur simply because larger fishes may be physically able to eat larger prey (Scharf et al. 2000), but such ontogenetic diet shifts may also indicate a change in nutritional requirements with development. Numerous studies have shown that fishes have the ability to select food based on their nutritional requirements 
Table 4. Pseudanthias rubrizonatus. One-way analysis of covariance on the effect of standard length (SL) and location on the $\delta^{13} \mathrm{C}$ values. (A) Interaction model, (B) interaction model with Yodel data removed, (C) main effects model with Yodel data removed, (D) interaction model with data from small fish $(<40 \mathrm{~mm})$ at Yodel removed

\begin{tabular}{|lccccc|}
\hline Source & SS & df & MS & $F$ & $\mathrm{p}$ \\
\hline (A) & & & & & \\
SL (covariate) & 10.628 & 1 & 10.628 & 40.591 & $<0.001$ \\
Location (factor) & 8.244 & 4 & 2.061 & 7.871 & $<0.001$ \\
Location $\times$ SL & 9.228 & 4 & 2.307 & 8.811 & $<0.001$ \\
Error & 54.461 & 208 & 0.262 & & \\
(B) & & & & & \\
SL (covariate) & 12.917 & 1 & 12.917 & 49.186 & $<0.001$ \\
Location (factor) & 0.934 & 3 & 0.311 & 1.186 & 0.317 \\
Location $\times$ SL & 0.426 & 3 & 0.142 & 0.541 & 0.655 \\
Error & 46.745 & 178 & 0.263 & & \\
(C) & & & & & \\
SL (covariate) & 23.269 & 1 & 23.269 & 89.286 & $<0.001$ \\
Location (factor) & 1.857 & 3 & 0.619 & 2.375 & 0.072 \\
Error & 47.172 & 181 & 0.261 & & \\
(D) & & & & & \\
SL (covariate) & 11.675 & 1 & 11.675 & 44.094 & $<0.001$ \\
Location (factor) & 1.262 & 4 & 0.315 & 1.191 & 0.316 \\
Location $\times$ SL & 1.064 & 4 & 0.266 & 1.004 & 0.406 \\
Error & 52.690 & 199 & 0.265 & & \\
\hline
\end{tabular}

Table 5. Pseudanthias rubrizonatus. One-way analysis of covariance on the effect of standard length (SL) and location on the $\delta^{15} \mathrm{~N}$ signatures. (A) Interaction model, (B) interaction model with Yodel data removed, (C) main effects model with Yodel data removed, (D) interaction model with data from small fish $(<40 \mathrm{~mm})$ at Yodel removed

\begin{tabular}{|lccccc|}
\hline Source & SS & df & MS & $F$ & $p$ \\
\hline (A) & & & & & \\
SL (covariate) & 17.998 & 1 & 17.998 & 41.165 & $<0.001$ \\
Location (factor) & 6.649 & 4 & 1.662 & 3.802 & 0.005 \\
Location $\times$ SL & 5.365 & 4 & 1.341 & 3.068 & 0.018 \\
Error & 90.942 & 208 & 0.437 & & \\
(B) & & & & & \\
SL (covariate) & 15.836 & 1 & 15.836 & 36.273 & $<0.001$ \\
Location (factor) & 2.287 & 3 & 0.762 & 1.746 & 0.159 \\
Location $\times$ SL & 1.835 & 3 & 0.612 & 1.401 & 0.244 \\
Error & 77.709 & 178 & 0.437 & & \\
(C) & & & & & \\
SL (covariate) & 40.977 & 1 & 40.977 & 93.241 & $<0.001$ \\
Location (factor) & 1.159 & 3 & 0.386 & 0.879 & 0.453 \\
Error & 79.544 & 181 & 0.439 & & \\
(D) & & & & & \\
SL (covariate) & 13.077 & 1 & 13.077 & 29.908 & $<0.001$ \\
Location (factor) & 4.302 & 4 & 1.075 & 2.460 & 0.047 \\
Location $\times$ SL & 3.982 & 4 & 0.996 & 2.277 & 0.062 \\
Error & 87.009 & 199 & 0.437 & & \\
\hline
\end{tabular}

position of these fish is higher (Wada et al. 1987), this would indicate that larger fish are at a higher trophic position than smaller fish. The only site where this did not occur was Yodel (Fig. 5), for unknown reasons.

$\delta^{13} \mathrm{C}$ values ranged from $-19.7 \%$ o for the smaller fish to $-16.2 \%$ for larger fish. The most likely source of primary productivity in the offshore environment is phytoplankton, the $\delta^{13} \mathrm{C}$ of which can range from -24 to $-18 \%$ (Fry \& Sherr 1984). However, variability in phytoplankton $\delta^{13} \mathrm{C}$ is strongly correlated with latitude south of the equator, becoming more enriched in warmer equatorial waters (Rau et al. 1982). There is a dearth of data regarding the biological oceanography of the North-West Shelf of Australia, but in the central Indian Ocean, mean $\delta^{13} \mathrm{C}$ ranged from -20.6 to $-19.2 \%$ between similar latitudes (10 to $28^{\circ} \mathrm{S}$ ) (Fontugne \& Duplessy 1978). The $\delta^{13} \mathrm{C}$ of mysids $\mathrm{B}$ indicates that their carbon source is most likely off-shore phytoplankton. However, the enrichment of the carbon signature with increasing fish size is indicative of more enriched carbon sources in the diet. Sources of carbon enrichment could include phytoplankton from higher latitudes (Rau et al. 1982), consumers at higher trophic levels, or enriched inshore resources such as seagrass and macroalgae (Fry \& Sherr 1984). However, access to inshore resources would require connectivity, e.g. through a planktonic species as discussed below.

Conclusions drawn from prey items taken from the guts should be interpreted with care. Changes in isotopic signatures due to assimilation during the digestive process were assumed to be small, but remain unproven. With this caveat in mind, analysis of isotope signatures from the 3 common prey items found in the guts indicated that the $\delta^{13} \mathrm{C}$ content of Pseudanthias rubri-

andthe nutritional quality of the food items available (Duffy \& Paul 1992, Sanchez-Vazquez et al. 1999, Simpson \& Raubenheimer 2001a,b, Raubenheimer et al. 2005, Rubio et al. 2006).

As Pseudanthias rubrizonatus grow larger they display more enriched content of both $\delta^{13} \mathrm{C}$ and $\delta^{15} \mathrm{~N}$. Since enriched $\delta^{15} \mathrm{~N}$ values suggest that the trophic zonatus most resembled the signature of the larval bregmacerotids. The similar $\delta^{13} \mathrm{C}$ content suggests that bregmacerotids are more often ecological competitors rather than prey for smaller individuals of $P$. rubrizonatus. The isotopic signatures of mysids B place these animals 1 trophic position below $P$. rubrizonatus (Fig. 4), and their isotopic signatures indicate they may 


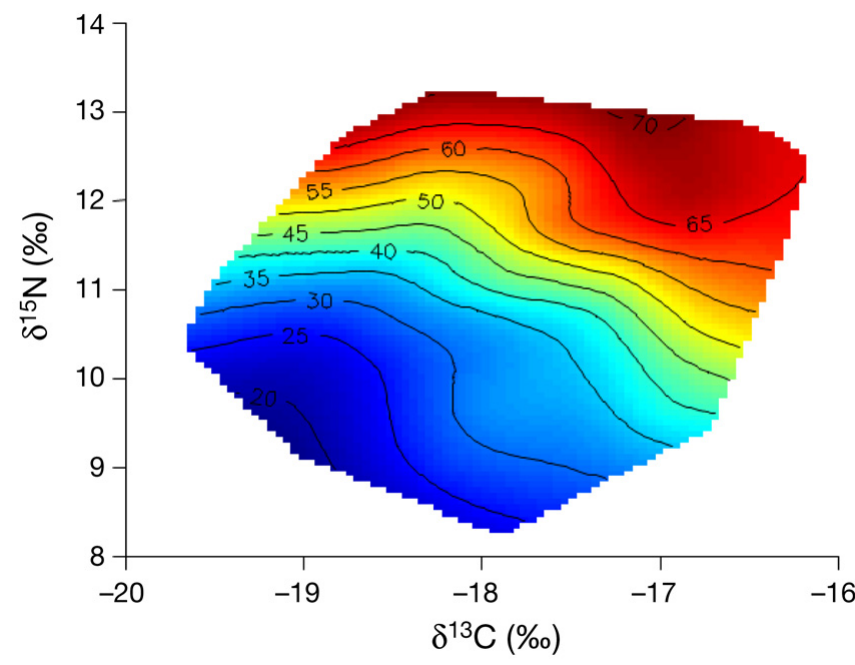

Fig. 6. Pseudanthias rubrizonatus. Body length plotted as a response surface onto values for $\delta^{13} \mathrm{C}$ vs. $\delta^{15} \mathrm{~N}$ isotopes. The response surface was fitted using a nonparametric spline surface with data from all locations pooled $(n=205)$

be the trophic link between the fishes and offshore phytoplankton resources. Isotope signatures of heteropods were the most different from the $\delta^{13} \mathrm{C}$ content of $P$. rubrizonatus, and we suggest that heteropods are not a common food source for $P$. rubrizonatus. $\delta^{13} \mathrm{C}$ content in heteropods indicates that these animals rely on enriched near-shore resources such as seagrass and algae (Fry \& Sherr 1984), implying trophic connectivity between near-shore resources and offshore communities. However, enriched offshore resources are plausible, as recent research has discovered the potential of some deeper water communities to support primary production, such as the deep-water Galapagos kelp forests (Graham et al. 2007). We recommend further investigation of trophic connectivity of planktonic communities between offshore and near-shore waters in this region. Investigations utilising fatty acid analysis could also identify links between species of interest and primary producers (Iverson et al. 2004).

Changes in stable isotope signatures indicated that all locations showed similar patterns in ontogenetic change for both $\delta^{13} \mathrm{C}$ and $\delta^{15} \mathrm{~N}$. As fish body lengths increased, both their $\delta^{13} \mathrm{C}$ and $\delta^{15} \mathrm{~N}$ became enriched, similar to other fish species such as smallmouth bass Micropterus dolomieu (Centrarchidae) (Vander Zanden et al. 1998). De Brabandere et al. (2009) used another isotope, $\delta^{13} \mathrm{~S}$, to show ontogenetic diet shifts in gizzard shad Dorosoma cepedianum (Clupeidae). A closer inspection of the body length data for our fish indicated that the change in isotope signatures was greatest in fish between 30 and $50 \mathrm{~mm}$ SL. Otolith analysis indicated that this length range represented the transition from juvenile to adult stages (A. Fowler unpubl. data). In contrast, yellowstripe goatfish Mul- loidichthys flavolineatus (Mullidae) displayed shifts in $\delta^{13} \mathrm{C}$ signatures between the juvenile and young adult stage, while trophic position $\left(\delta^{15} \mathrm{~N}\right)$ did not change greatly until the adult stage (Kolasinski et al. 2009). The pattern of the small fish in our study displaying lower stable isotope values for both $\delta^{13} \mathrm{C}$ and $\delta^{15} \mathrm{~N}$ was evident at all locations with the exception of Yodel. It was clear at Yodel that the smaller fish were higher in $\delta^{15} \mathrm{~N}$ (hence, presumably higher in trophic position) but not in $\delta^{13} \mathrm{C}$ compared to the smaller fish at all other sites. Perhaps food resources were more limited at Yodel than at the other locations, forcing smaller fish to utilise similar resources to the larger fish. However, further investigation of resources at these locations is required to determine the reason for the observed differences at Yodel.

In marine ecosystems, the assemblage of prey items may vary temporally (Benoit-Bird \& Au 2003, Estes et al. 2003, Takeuchi et al. 2006). This level of variation would be expected to increase for opportunistic species such as Pseudanthias rubrizonatus (Möller \& Rosenberg 1982). The results show that the 2 samplings at the Goodwyn location contained different prey assemblages, indicating that for P. rubrizonatus, the interpretation of results is limited and conclusions regarding temporal patterns cannot be made by gut analysis alone unless the same population can be re-sampled on numerous occasions. Unfortunately for these populations, like many other rare and inaccessible species, this was not possible.

In conclusion, these results show that the reef fish Pseudanthias rubrizonatus predominantly feeds upon resources within the water column, but will opportunistically exploit other resources, including benthic and pelagic prey items. Pelagic prey items may provide important links in the food web between the reef fishes on these isolated structures and primary production sources. Additionally, the results show that this species undergoes an ontogenetic diet shift after about 1 yr of age. We show that the approach of combining gut content with stable isotope analysis allows partial access to the nutritional ecology and trophic interactions of inaccessible species such as P. rubrizonatus.

Acknowledgements. We thank S. Holmes, F. Clissold and A. Fowler for valuable comments and assistance in the preparation of this manuscript; the captain, business partners and crew of CV 'Havila Harmony' for assistance on board with the collection of the animals; SEA SERPENT personnel who assisted in the field; and Woodside Petroleum who made this research possible by providing access and logistical support. This research was funded by the Australian Research Council grant LP0775183. This paper is contribution no. 6 from the South East Asian Branch of the Scientific and Environmental Remotely Operated Vehicle Partnership using Existing Industrial Technology (SERPENT) deep-sea project and constitutes a portion of the $\mathrm{PhD}$ thesis of D.O.C. We thank 3 anonymous reviewers for comments that improved this manuscript. 


\section{LITERATURE CITED}

Allen G (1997) Marine fishes of tropical Australia and SouthEast Asia. Western Australian Museum, Perth

- Avise JC, Shapiro DY (1986) Evaluating kinship of newly settled juveniles within social groups of the coral reef fish Anthias squamipinnis. Evolution 40:1051-1059

Benoit-Bird KJ, Au WWL (2003) Prey dynamics affect foraging by a pelagic predator (Stenella longirostris) over a range of spatial and temporal scales. Behav Ecol Sociobiol 53:364-373

> Caselle JE, Love MS, Fusaro C, Schroeder D (2002) Trash or habitat? Fish assemblages on offshore oilfield seafloor debris in the Santa Barbara Channel, California. ICES J Mar Sci 59:S258-S265

> Cherel Y, Hobson KA, Bailleul FR, Groscolas R (2005) Nutrition, physiology, and stable isotopes: new information from fasting and molting penguins. Ecology 86:2881-2888

Clarke LR, Vidergar DT, Bennett DH (2005) Stable isotopes and gut content show diet overlap among native and introduced piscivores in a large oligotrophic lake. Ecol Freshw Fish 14:267-277

> Clements KD, Choat JH (1993) Influence of season, ontogeny and tide on the diet of the temperate marine herbivorous fish Odax pullus (Odacidae). Mar Biol 117:213-220

Cortes E (1997) A critical review of methods of studying fish feeding based on analysis of stomach contents: application to elasmobranch fishes. Can J Fish Aquat Sci 54:726-738

> De Brabandere L, Catalano MJ, Frazer TK, Allen MS (2009) Stable isotope evidence of ontogenetic changes in the diet of gizzard shad Dorosoma cepedianum. J Fish Biol 74: 105-119

DeNiro MJ, Epstein S (1978) Influence of diet on distribution of carbon isotopes in animals. Geochim Cosmochim Acta 42:495-506

Duffy JE, Paul VJ (1992) Prey nutritional quality and the effectiveness of chemical defenses against tropical reef fishes. Oecologia 90:333-339

Eggold BT, Motta PJ (1992) Ontogenetic dietary shifts and morphological correlates in striped mullet, Mugil cephalus. Environ Biol Fishes 34:139-158

Estes JA, Riedman ML, Staedler MM, Tinker MT, Lyon BE (2003) Individual variation in prey selection by sea otters: patterns, causes and implications. J Anim Ecol 72:144-155

Fontugne M, Duplessy JC (1978) Carbon isotope ratio of marine plankton related to surface-water masses. Earth Planet Sci Lett 41:365-371

Fry B, Sherr EB (1984) $\delta^{13} \mathrm{C}$ measurements as indicators of carbon flow in marine and fresh-water ecosystems. Contrib Mar Sci 27:13-47

Gannes LZ, Obrien DM, delRio CM (1997) Stable isotopes in animal ecology: assumptions, caveats, and a call for more laboratory experiments. Ecology 78:1271-1276

Garicía-Berthou E, Moreno-Amich R (2000) Food of introduced pumpkinseed sunfish: ontogenetic diet shift and seasonal variation. J Fish Biol 57:29-40

> German DP, Horn MH (2006) Gut length and mass in herbivorous and carnivorous prickleback fishes (Teleostei: Stichaeidae): ontogenetic, dietary, and phylogenetic effects. Mar Biol 148:1123-1134

Gill AB, Hart PJB (1999) Dynamic changes in prey choice by stickleback during simultaneous encounter with large prey. J Fish Biol 55:1317-1327

- Graham MH, Kinlan BP, Druehl LD, Garske LE, Banks S (2007) Deep-water kelp refugia as potential hotspots of tropical marine diversity and productivity. Proc Natl Acad Sci USA 104:16576-16580
Hesslein RH, Hallard KA, Ramlal P (1993) Replacement of sulfur, carbon, and nitrogen in tissue of growing broad whitefish (Coregonus nasus) in response to a change in diet traced by $\delta^{34} \mathrm{~S}, \delta^{13} \mathrm{C}$ and $\delta^{15} \mathrm{~N}$. Can J Fish Aquat Sci 50: 2071-2076

Hobson KA (1999) Tracing origins and migration of wildlife using stable isotopes: a review. Oecologia 120:314-326

Hood PB, Godcharles MF, Barco RS (1994) Age, growth, reproduction, and the feeding ecology of black sea bass, Centropristis striata (Pisces, Serranidae), in the eastern Gulf of Mexico. Bull Mar Sci 54:24-37

Horn MH (1989) Biology of marine herbivorous fishes. Oceanogr Mar Biol Annu Rev 27:167-272

> Hyslop EJ (1980) Stomach contents analysis - a review of methods and their application. J Fish Biol 17:411-429

$>$ Iverson SJ, Field C, Bowen WD, Blanchard W (2004) Quantitative fatty acid signature analysis: a new method of estimating predator diets. Ecol Monogr 74:211-235

Jackson AC, Rundle SD (2008) Diet-shifts by an estuarine goby (Pomatoschistus microps) in the face of variable prey availability. J Exp Mar Biol Ecol 361:1-7

Jolliffe IT (2004) Principle component analysis. Springer, New York, NY

Kapoor BG, Smit H, Verighina IA (1975) Alimentary canal and digestion in teleosts. Adv Mar Biol 13:109-239

Kingsford MJ (1992) Spatial and temporal variation in predation on reef fishes by coral trout (Plectropomus leopardus, Serranidae). Coral Reefs 11:193-198

> Kolasinski J, Frouin P, Sallon A, Rogers K, Bruggemann HJ, Potier M (2009) Feeding ecology and ontogenetic dietary shift of yellowstripe goatfish Mulloidichthys flavolineatus (Mullidae) at Reunion Island, SW Indian Ocean. Mar Ecol Prog Ser 386:181-195

Laptikhovsky VV (2005) A trophic ecology of two grenadier species (Macrouridae, Pisces) in deep waters of the Southwest Atlantic. Deep-Sea Res I 52:1502-1514

Liem KF (1980) Adaptive significance of intraspecific and interspecific differences in the feeding repertoires of cichlid fishes. Am Zool 20:295-314

Love MS, York A (2005) A comparison of the fish assemblages associated with an oil/gas pipeline and adjacent seafloor in the Santa Barbara Channel, southern California bight. Bull Mar Sci 77:101-117

Love MS, Casellle J, Snook L (1999) Fish assemblages on mussel mounds surrounding seven oil platforms in the Santa Barbara channel and Santa Maria basin. Bull Mar Sci 65:497-513

Love MS, Schroeder DM, Lenarz W, MacCall A, Bull AS, Thorsteinson L (2006) Potential use of offshore marine structures in rebuilding an overfished rockfish species, bocaccio (Sebastes paucispinis). Fish Bull 104:383-390

> Miller MW (2002) Using ecological processes to advance artificial reef goals. ICES J Mar Sci 59:S27-S31

> Minagawa M, Wada E (1984) Stepwise enrichment of ${ }^{15} \mathrm{~N}$ along food-chains - further evidence and the relation between delta $\delta^{15} \mathrm{~N}$ and animal age. Geochim Cosmochim Acta 48:1135-1140

Möller P, Rosenberg R (1982) Production and abundance of the amphipod Corophium volutator on the west coast of Sweden. Neth J Sea Res 16:127-140

$>$ Morato T, Santos RS, Andrade JP (2000) Feeding habits, seasonal and ontogenetic diet shift of blacktail comber, Serranus atricauda (Pisces: Serranidae), from the Azores, north-eastern Atlantic. Fish Res (Amst) 49:51-59

Muñoz AA, Ojeda FP (1998) Guild structure of carnivorous intertidal fishes of the Chilean coast: implications of ontogenetic dietary shifts. Oecologia 114:563-573 
Olson MH (1996) Ontogenetic niche shifts in largemouth bass: variability and consequences for first-year growth. Ecology 77:179-190

Page HM, Dugan JE, Schroeder DM, Nishimoto MM, Love MS, Hoesterey JC (2007) Trophic links and condition of a temperate reef fish: comparisons among offshore oil platform and natural reef habitats. Mar Ecol Prog Ser 344: 245-256

Paradis Y, Bertolo A, Magnan P (2008) What do the empty stomachs of northern pike (Esox lucius) reveal? Insights from carbon $\left(\delta^{13} \mathrm{C}\right)$ and nitrogen $\left(\delta^{15} \mathrm{~N}\right)$ stable isotopes. Environ Biol Fishes 83:441-448

Perga ME, Gerdeaux D (2005) 'Are fish what they eat' all year round? Oecologia 144:598-606

Post DM (2002) Using stable isotopes to estimate trophic position: models, methods, and assumptions. Ecology 83: 703-718

Quevedo M, Svanback R, Eklov P (2009) Intrapopulation niche partitioning in a generalist predator limits food web connectivity. Ecology 90:2263-2274

Quinn GP, Keough MJ (2002) Experimental design and data analysis for biologists. Cambridge University Press, Cambridge

Randall JE (1983) A new fish of the genus Anthias (Perciformes: Serranidae) from the western Pacific, with notes on A. luzonensis. Freshw Mar Aquar 6:27-37

Rau GH, Sweeney RE, Kaplan IR (1982) Plankton ${ }^{13} \mathrm{C}:{ }^{12} \mathrm{C}$ ratio changes with latitude: differences between northern and southern oceans. Deep-Sea Res I 29:1035-1039

Raubenheimer D, Zemke-White WL, Phillips RJ, Clements KD (2005) Algal macronutrients and food selection by the omnivorous marine fish Girella tricuspidata. Ecology 86: $2601-2610$

Rubio VC, Sánchez-Vázquez FJ, Madrid JA (2006) Influence of nutrient preload on encapsulated macronutrient selection in European sea bass. Physiol Behav 89:662-669

Samoilys MA (1997) Movement in a large predatory fish: coral trout, Plectropomus leopardus (Pisces: Serranidae), on Heron Reef, Australia. Coral Reefs 16:151-158

Sanchez-Vazquez FJ, Yamamoto T, Akiyama T, Madrid JA, Tabata M (1999) Macronutrient self-selection through demand-feeders in rainbow trout. Physiol Behav 66:45-51

Santos MN, Monteiro CC (2007) A fourteen-year overview of the fish assemblages and yield of the two oldest Algarve artificial reefs (southern Portugal). Hydrobiologia 580: $225-231$

Scharf FS, Juanes F, Rountree RA (2000) Predator size-prey size relationships of marine fish predators: interspecific variation and effects of ontogeny and body size on trophicniche breadth. Mar Ecol Prog Ser 208:229-248

Schleuter D, Eckmann R (2008) Generalist versus specialist: the performances of perch and ruffe in a lake of low productivity. Ecol Freshw Fish 17:86-99

Shapiro DY (1988) Variation of group composition and spatial structure with group size in a sex-changing fish. Anim Behav 36:140-149

Shapiro D (1990) Sex-changing fish as a manipulable system for the study of the determination, differentiation, and stability of sex in vertebrates. J Exp Zool 256:132-136

Shapiro DY, Genin A (1993) Feeding whorl induced by strong current in a planktivorous reef fish. Copeia 1993:542-545
Simpson SJ, Raubenheimer D (2001a) A framework for the study of macronutrient intake in fish. Aquacult Res 32:421-432

Simpson SJ, Raubenheimer D (2001b) The geometric analysis of nutrient-allelochemical interactions: a case study using locusts. Ecology 82:422-439

$>$ St John J (1999) Ontogenetic changes in the diet of the coral reef grouper Plectropomus leopardus (Serranidae): patterns in taxa, size and habitat of prey. Mar Ecol Prog Ser 180:233-246

Takeuchi T, Shiraki S, Nashimoto M, Matsuki R, Abe S, Yatake H (2006) Regional and temporal variations in prey selected by golden eagles Aquila chrysaetos during the nestling period in Japan. Ibis 148:79-87

Underwood AJ (1981) Techniques of analysis of variance in experimental marine biology and ecology. Oceanogr Mar Biol Annu Rev 19:513-605

Vander Zanden MJ, Hulshof M, Ridgway MS, Rasmussen JB (1998) Application of stable isotope techniques to trophic studies of age-0 smallmouth bass. Trans Am Fish Soc 127:729-739

Wada E, Terazaki M, Kabaya Y, Nemoto $\mathrm{T}$ (1987) ${ }^{15} \mathrm{~N}$ and ${ }^{13} \mathrm{C}$ abundances in the Antarctic Ocean with emphasis on the biogeochemical structure of the food web. Deep-Sea Res I 34:829-841

Wagner CE, McIntyre PB, Buels KS, Gilbert DM, Michel E (2009) Diet predicts intestine length in Lake Tanganyika's cichlid fishes. Funct Ecol 23:1122-1131

Ward AJW, Webster MM, Hart PJB (2006) Intraspecific food competition in fishes. Fish Fish 7:231-261

Ward-Campbell BMS, Beamish FWH (2005) Ontogenetic changes in morphology and diet in the snakehead, Channa limbata, a predatory fish in western Thailand. Environ Biol Fishes 72:251-257

Webb SC, Simpson SJ, Hedges REM (1998) The effect of diet quality on $\delta^{13} \mathrm{C}$ and $\delta^{15} \mathrm{~N}$ in the tissues of locusts, Locusta migratoria L. Isot Environ Health Stud 34:43-51

Wells RJD, Cowan JH Jr, Fry B (2008) Feeding ecology of red snapper Lutjanus campechanus in the northern Gulf of Mexico. Mar Ecol Prog Ser 361:213-225

> Werner EE, Gilliam JF (1984) The ontogenetic niche and species interactions in size structured populations. Annu Rev Ecol Syst 15:393-425

Wiens JA (1993) Fat times, lean times and competition among predators. Trends Ecol Evol 8:348-349

- Wilding TA, Sayer MDJ (2002) Evaluating artificial reef performance: approaches to pre- and post-deployment research. ICES J Mar Sci 59:S222-S230

Wimberger PH (1992) Plasticity of fish body shape-the effects of diet, development, family and age in two species of Geophagus (pisces, cichlidae). Biol J Linn Soc 45: $197-218$

Wolfson A, Van Blaricom G, Davis N, Lewbel GS (1979) The marine life of an offshore oil platform. Mar Ecol Prog Ser $1: 81-89$

> Yohannes E, Hansson B, Lee RW, Waldenström J and others (2008) Isotope signatures in winter moulted feathers predict malaria prevalence in a breeding avian host. Oecologia 158:299-306

Zar JH (1984) Biostatistical analysis. Prentice Hall, Upper Saddle River, NJ

Submitted: February 5, 2010; Accepted: September 13, 2010 Proofs received from author(s): November 17, 2010
Editorial responsibility: Hans Heinrich Janssen,

Oldendorf/Luhe, Germany 